\title{
KARAKTERISTIK KEPEMIMPINAN PENDIDIKAN ISLAM BERBASIS MASJID
}

\author{
M.Hidayat Ginanjar, Wartono \\ Jurusan Tarbiyah STAI Al-Hidayah Bogor \\ e-mail:m.hidayatginanjar@gmail.com
}

\begin{abstract}
Leadership is the ideal of quality, both in terms of physical, mental, and intellectual. Maturity in terms ofthis aspect will help a leader in carrying out the task. Knowledge and a wide perspective is the key in solving many problems that block or make some breakthroughs for the success of the important task of a leader. Islam encourage every Muslim to have these three types of power. The strong and good believers are well loved by Allah more than the weak believers, each has a virtue. For that, the vision and values of leadership comes from the ideal practices of Rasulullah peace be upon him (Shalallahu 'alaihi wa sallam) and the Companions, it is necessary and must continue to be extracted, distributed and socialized to become a strong issue in the stage of leadership in society. Therefore, a good leadership is absolutely needed by the community, and of course the leaders are expected to appear is a leader that has a nature or character laudable. That is, on the side of truth, justice, has the nature of trust, a worthy model, simplicity, greatness of the soul, forgive person, and others who emphasize kindness for the people. One of the leadership Islamic education models is leadership based mosque, the mosque is a place where Muslims join together in routines worship, both (hablum minallah) (relationship between human and Allah) or (hablum minannas) (relationship between human and human). For Muslims, the mosque become the heart moorings, the port development and the life energy of Muslims. mosques also function as institutions of education and knowledge of Islam. In addition, the mosque is also a place that can be delivered candidates Islamic leaders in the future, as evidenced (applied) by Rasulullah peace be upon him (Shalallahu 'alaihi wa sallam), he built with the friends so that future generations be able to lead the best and people through developments that centred in mosque. People were educated in mosques in a shelter of the high Islamic society and give priority in deliberation for solving problems. The mosque which was established on the basis of devotion to Allah will inure to the influence of education in human life. Thus, the mosque-based leadership can bear a good leader, the leader of a people-oriented development, so that it can be delivered to devotee individuals, able to lead and bring the next generation achieve their hopes; establishing a believer for himself, family, community, nation and state.
\end{abstract}

Keyword: Islamic Education, Leadership, Caracter, Mosqul Based.

\begin{abstract}
ABSTRAK
Kepemimpinan adalah kualitas ideal, baik dari segi fisik, mental intelektual. Kedewasaan dalam hal aspek ini akan membantu seorang pemimpin dalam menjalankan tugasnya. Pengetahuan dan perspektif yang luas adalah kunci dalam memecahkan banyak masalah yang membuat terobosan bagi keberhasilan tugas penting seorang pemimpin. Islam mendorong setiap muslim untuk memiliki ketiga jenis kekuasaan ini. Orang-orang terpercaya dan kuat lebih dicintai Allah dan lebih
\end{abstract}

Jurnal Manajemen Pendidikan Islam, Volume.I, Nomor.1, Januari 2018

P-ISSN : 2614-8846 ; E-ISSN : 2614-4018

Page 1 
baik dari orang-orang yang lemah, masing-masing memiliki kebajikan. Untuk itu, visi dan nilai kepemimpinan berasal dari praktik ideal Rasulullah Shallallahu alaihi wasallam dan para Sahabat, perlu dan harus terus didistribusikan dan disosialisasikan untuk menjadi isu kuat dalam tahap kepemimpinan di masyarakat. Oleh karena itu, kepemimpinan yang baik sangat dibutuhkan oleh masyarakat, dan tentu saja pemimpin diharapkan memiliki sifat atau karakter terpuji, yaitu, di sisi kebenaran, keadilan, memiliki sifat kepercayaan, model yang layak, kesederhanaan, kebesaran jiwa, berjiwa besar, dan lain-lain yang menekankan kebaikan bagi rakyat. Salah satu kepemimpinan model pendidikan Islam adalah kepemimpinan berbasis masjid. Masjid adalah tempat dimana umat Islam bergabung bersama dalam ibadah rutin, baik hubungan antara manusia dan Allah atau hubungan antara manusia dan manusia. Bagi umat Islam, masjid menjadi tambatan hati, pembangunan pelabuhan dan energi kehidupan umat Islam. Masjid juga berfungsi sebagai institusi pendidikan dan perdaban Islam. Selain itu, masjid juga merupakan tempat yang bisa mengantarkan calon pemimpin di masa depan, sebagaimana diterapkan oleh Rasulullah Shallallahu alaihi wasallam, la membangun masjid bersama para sahabatnya sehingga menjadi generasi penerus umat terbaik melalui pembinaan yang berpusat di masjid. Orang-orang besar itu dididik di masjid yang merupakan tempat pembinaan masyarakat Islami juga dapat memecahkan permasalahan umat. Masjid yang didirikan atas dasar pengabdian kepada Allah akan sesuai dengan pengaruh pendidikan dalam kehidupan manusia. Dengan demikian, kepemimpinan berbasis masjid dapat melahirkan pemimpin yang baik, pemimpin pembangunan yang visioner sehingga mampu memimpin dan membawa generasi penerus mencapai cita-cita mereka dengan penuh amanah, baik untuk dirinya sendiri, keluarga, masyarakat, bangsa dan negara.

\section{Key Word : pendidikan Islam, kepemimpinan, karakter, berbasis masjid.}

\section{PENDAHULUAN}

Berbagai persoalan yang kini menimpa umat di berbagai lapangan kehidupan berakar dari hilangnya "Visi dan Karakter Kepemimpinan Islami" dalam diri para pemimpin itu. Mencari pemimpin yang memiliki visi dan praktek kepemimpinan yang baik begitu sulit. Kepemimpinan yang semestinya difahami sebagai amanah, malah dirasakan sebagai kekuasaan. Pemimpin yang semestinya menjadi pelayan, berubah menjadi penguasa yang menindas dan mengatur semua urusan dengan mengikuti hawa nafsunya. Kezaliman dan pengkhianatan akhirnya dirasakan hanya sebagai kealpaan kecil yang harus dimaafkan dalam kultur mayoritas masyarakat muslim.

Krisis kepemimpinan dapat terjadi karena banyak hal, di antaranya masyarakat merasa tidak memiliki pemimpin yang amanah, adil dan tegas serta berpihak pada kepentingan seluruh rakyatnya terutama pada kalangan yang masih hidup dalam kondisi yang sulit. Namun, harapan rakyat lapisan bawah masih tetap optimis akan tampilnya figur yang memiliki karakteristik 
pemimpin yang ideal seperti memiliki visi dan komitmen pada visinya, kompetensi, integritas, kejujuran, kesediaan mendengar, dan menerima kritik serta masukan, tidak diktator dalam membuat dan menetapkan suatu kebijakan-kebijakannya. Penyebab penting lainnya, adalah kurangnya kontrol bawahan atau masyarakat terhadap kinerja dan perilaku para pemimpin sehingga makin memperparah situasi krisis yang menjadi penyebab kegaduhan sosial. Memang terjadinya krisis kepemimpinan di tengah-tengah umat dimulai dari berubahnya persepsi yang benar tentang suatu paradigma kepemimpinan.

Sementara itu, terjadinya krisis kepemimpinan di tengah-tengah umat dimulai dari berubahnya persepsi yang benar tentang kepemimpinan. Selain itu, kuatnya cengkeraman budaya dan praktik-praktik kepemimpinan kotor yang disaksikan sehari-hari, membuat masyarakat memandang terhadap praktik kemungkaran dan kezaliman sebagai hal yang biasa. Padahal, pemimpin yang sejati adalah pelayan bagi umat, malah berubah menjadi tirani yang berbuat sewenang-wenang terhadap bawahannya. Kekuasaan yang semestinya mengharuskan dirinya melayani rakyat, justru dijadikan sarana untuk memaksakan kehendak dan kepentingan atau ambisi pribadinya.

Untuk itu, visi dan nilai kepemimpinan ideal yang bersumber dari praktik-praktik kepemimpinan Rasulullah, Nabi Muhammad (S.A.W) dan para sahabatnya, sangat perlu dan harus terus digali, disebarkan dan ditradisikan agar menjadi isu kuat dalam mencerahkan paradigma umat termasuk dalam hal berpolitik dalam kancah suksesi kepemimpinan di masyarakat. Petunjuk Islam dalam kepemimpinan ini adalah merupakan kekayaan (turats) bagi umat manusia yang bisa ditemukan dalam berbagai literatur sejarah, seperti Sirah Nabawiyah, Sirah Shahabat, Tarikh Al-Thabary, Sirah Ibnu Hisyam, dan lainnya.

Oleh karena itu, kepemimpinan yang baik sangat mutlak dibutuhkan oleh umat, dan tentunya pemimpin masa depan yang diharapkan tampil adalah pemimpin yang memiliki sifat-sifat atau karakter terpuji, yakni yang berpihak pada kebenaran, keadilan, memiliki sifat amanah, jujur, keteladan, kesederhanaan, kebesaran jiwa, pemaaf, dan lain-lainnya yang mementingkan kemaslahatan bagi umat manusia. Karenanya, pemimpin 
membutuhkan arahan (taujih) dan latihan sejak dini, bisa didapatkan dari orang tua, guru, keluarga, sekolah, dan lingkungan masyarakat.

Salah satu model kepemimpinan pendidikan perspektif Islam adalah kepemimpinan berbasis masjid, yang mana masjid adalah tempat bersatunya umat Islam dalam pelaksanaan peribadahan, baik ibadah secara vertikal kepada Allah (S.W.T) (hablum minallah) maupun ibadah yang terkait dengan sesama manusia atau yang disebut (hablum minannas). Karena itu, umat Islam wajib memakmurkan masjid, karena masjid merupakan tempat peribadatan, sarana pembinaan umat dan juga menjadi media efektif dalam mempersatukan umat Islam. Orang yang memakmurkan masjid itu adalah orang yang jelas terbukti keimanannya, dan ia hanya takut kepada Allah dan takut ancaman neraka-Nya. Allah (S.W.T) berfirman Alqur'an surat AtTaubah ayat 18; "Hanya yang memakmurkan masjid-masjid Allah ialah orang-orang yang beriman kepada Allah dan Hari kemudian, serta tetap mendirikan shalat, menunaikan zakat dan tidak takut (kepada siapapun) selain kepada Allah, maka merekalah orang-orang yang diharapkan termasuk golongan orang-orang yang mendapat petunjuk". (QS. At Taubah: 18).

Berdasarkan firman Allah di atas, bahwa kriteria seorang Takmir masjid itu adalah yang memiliki beberapa komitmen sebagai berikut: 1) Iman kepada Allah (S.W.T) dan Hari akhir; 2) Tidak mempersekutukan Allah SWT; 3) Menegakkan shalat; 4) Menunaikan Zakat; dan 5) Independen (mandiri, istiqlal) dan tidak takut kepada siapa pun selain kepada Allah S.W.T.

Dengan demikian, maka masjid didirikan untuk memenuhi kebutuhan Umat Islam, khususnya kebutuhan spiritual untuk mendekatkan dirinya kepada Allah (S.W.T) Masjid menjadi tambatan hati, pelabuhan pengembangan hidup dan energi kehidupan umat Islam. Karena itu, masjid jangan dijadikan sebagai alat untuk memecah belah umat Islam, sebagaimana intrik yang dilakukan kaum munafik dahulu dengan mendirikan masjid dhirar-nya Bahkan, masjid yang seperti itu tidak layak bagi umat Islam untuk beribadah di dalamnya. Sebagaimana pula ditegaskan Allah dalam Alqur'an surat At-taubah ayat ke 108.

Secara khusus, masjid merupakan tempat dilangsungkannya ibadah shalat. Di sanalah tempat perjumpaan orang-orang yang patuh dan tunduk 
kepada aturan Allah (S.W.T) la merupakan taman keimanan dan pahala,seperti yang telah dikatakan oleh Rasulullah (SAW), "Apabila kalian melihat seseorang yang terbiasa (memakmurkan) Masjid maka saksikanlah bahwasanya ia beriman." (HR. Ahmad dan At Tirmidzi). (Hamad Hasan Raqith, 2001: 79).

Di samping itu masjid juga merupakan taman ilmu, dzikir dan sarana dakwah. Rasulullah (SAW) Bersabda, "Tidaklah suatu kaum yang duduk di dalam suatu rumah Allah (S.W.T), mereka membaca kitab Allah (S.W.T) dan saling mempelajarinya kecuali mereka dikelilingi para malaikat, dinaungi rahmat Allah (S.W.T) dan diturunkan kepada mereka ketenangan (sakinah) dan mereka disebutkan oleh Allah (S.W.T) termasuk orang-orang yang berada di sisi-Nya." (HR. Muslim).

Makna sakinah yaitu berupa ketenangan dan ketentraman jiwa yang dapat menghilangkan kegundahan, keguncangan dan penyakit hati serta menghilangkan rasa dengki (hasad atau ghill) dan takut pada selain Allah (S.W.T).

Selain sebagai tempat shalat, masjid juga memiliki fungsi-fungsi lain. Di dalam masjid, jama'ah juga bermusyawarah, baik secara formal terarah, maupun secara spontan antara individu dengan individu, atau antar kelompok. Berbagai pendidikan juga terselenggara di masjid. Sebagaimana pula yang pernah terjadi di masa Nabi Muhammad Shallallahu 'alaihi wasallama ataupun 3 di masa sesudahnya, masjid menjadi pusat kegiatan kaum muslimin. Kegiatan di bidang pengetahuan, termasuk idiologi, politik, ekonomi, sosial, peradilan, dan kemiliteran didiskusikan di masjid, berfungsi pula sebagai tempat pengembangan kebudayaan Islam, terutama pada saat gedung-gedung khusus untuk kegiatan itu belum sempat didirikan.Masjid juga merupakan tempat halaqah atau diskusi, tempat mengkaji untuk memperdalam ilmu pengetahuan agama dan pengetahuan umum. Dalam arti lain, bahwa masjid berfungsi sebagai sebuah lembaga pendidikan Islam.

Sejalan dengan fungsi masjid. M.Athiyah Al-Abrasy mengatakan, bahwa dalam masa keemasan Islam yang pertama, pemuda-pemuda dan orang-orang yang telah berumur bersama-sama duduk di masjid untuk mengikuti pendidikan, yakni pelajaran-pelajaran yang diberikan, dan di 
antara mereka yang telah menjadi siswa di masjid adalah Ali bin Abi Thalib dan Abdullah Ibn Abbas (M. Athiyah al-Abrasyi: 1990: 58).

Oleh karenanya, pendidikan Islam erat sekali hubungannya dengan Masjid. Masjid bermanfaat untuk tempat beribadah dan sebagai lembaga pendidikan yang mengajarkan berbagai pengetahuan. Selain itu, masjid juga merupakan tempat pengkaderan yang dapat melahirkan calon-calon pemimpin Islam di masa yang akan datang, sebagaimana yang dibuktikan (diterapkan) Rasulullah (SAW) dengan membina para sahabatnya sehingga menjadi generasi terbaik dan mampu memimpin umatnya melalui pola pembinaan-pembinaan yang beliau pusatkan di masjid.

Mengingat betapa pentingnya keberadaan masjid dan Imam masjid dan betapa besar tanggungjawab yang diembannya, dalam tulisan ini penulis mencoba untuk mengemukakan pembahasan tentang model kepemimpinan pendidikan Islam berbasis masjid, juga pengaruh masjid terhadap pendidikan dan hal-hal lain-lain yang berhubungan dengannya.

\section{Manusia Tercipta Sebagai Pemimpin}

Dalam pandangan Islam, setiap manusia diciptakan oleh Allah (S.W.T) sebagai pemimpin, hal ini tentu saja sesuai dengan kapasitas yang dimilikinya.Inti kepemimpinan adalah tanggungjawab dan amanah. Dalam sebuah hadits, Rasulullah (SAW) menyatakan bahwa, "Setiap kamu adalah pemimpin dan setiap pemimpin akan ditanya tentang tanggungjawab kepemimpinannya". (H.R. Al Bukhari dan Muslim).

Dalam hadits tersebut, Rasulullah (SAW) menekankan perkataan "tanggungjawab". Sekecil apapun atau sesingkat apapun kepemimpinan seseorang, pasti akan ditanya oleh Allah (S.W.T) tentang keputusan (kebijakan) dalam kepemimpinannya. Oleh karena itu, hubungan kepemimpinan bukan hanya masalah hubungan manusia dengan manusia (hablum minannaas), bukan sekedar mu'amalah, tetapi juga berkaitan dengan masalah aqidah dan keyakinan.Karena fungsinya yang demikian penting, yang bisa menentukan kualitas masyarakat, maka dalam berbagai hadits diungkapkan bahwa ada berbagai syarat kepemimpinan yang harus terpenuhi. Adapun syarat kepemimpinan menurut pandangan Islam adalah sebagai berikut: 
Pertama, seorang pemimpin haruslah orang yang beriman dan bukan orang kafir. Hal tersebut sejalan dengan perintah Allah (S.W.T) dalam AlQur'an surat At-Taubah ayat 23.

Kemudian, Islam juga telah melarang setiap mukmin memilih orang kafir sebagai pemimpin dari kalangan Yahudi dan Nashara. Hal ini ditegaskan Allah dalam Alqur'an surat Al-Maidah ayat 51.

Kedua, pemimpin adalah orang yang dicintai oleh masyarakatnya, bukan ditakuti. Karena ketaatan yang didasari oleh kecintaan akan berbeda dengan ketaatan atas dasar takut. Kalau ketaatan didasari oleh kecintaan, maka biasanya ketaatan itu akan abadi. Tapi jika ketaatan itu atas dasar rasa takut, maka biasanya ketaatan itu sifatnya sementara. Maka wajar jikamasyarakat pun terpaksa patuh pada kebijakannya, karena memang dasarnya karena mereka takut.

Ketiga, pemimpin adalah orang yang menegakkan shalat dan menunaikan zakat, rela mengeluarkan hartanya untk kepentingan bersama. Dalam Alqur'an surat Al-Ma'idah ayat 55-56.

Keempat, bahwa pemimpin adalah mereka yang mempunyai kemampuan yang terbaik dan punya prestasi di masyarakatnya.

\section{Sistem Kepemimpinan Masjid}

\section{Kriteria Imam Masjid}

Mengingat betapa penting keberadaan imam dalam masjid dan betapa besar tanggungjawab yang diembannya, maka tugas ini tidak dapat dipegang oleh sembarang orang, apalagi karena ambisi dan mengejar keuntungan materi semata-mata, akan tetapi mestioleh orang yang pada pribadinya telah melekat syarat-syarat sebagaiberikut, sebagaimana hadits yang diriwayatkan oleh Ibnu Mas'ud, dia berkata. Rasulullah (SAW) telah bersabda; "Yang pantas dijadikan imam oleh suatu kaum (jama'ah) adalah yang paling ahli membaca Kitab Allah (Alqur'an) dan paling awal (belajar) membacanya. Apabila bacaannya sama, maka hendaklah mereka bermakmum kepada yang paling dahulu hijrahnya. Apabila dalam hijrahnya pun mereka sama, maka hendaklah mereka bermakmum kepada yang paling tua usianya. Sungguh janganlah sekali-kali engkau mengimami seseorang di dalam keluarganya dan kekuasaannya, dan janganlah engkau 
duduk di tempatnya yang khusus di rumahnya kecuali dia mengizinkan atau dengan seizinnya". (H.R. Muslim).

Dari penjelasan hadits di atas, dapat difahami bahwa karakteristik Imam Masjid adalah orang yang diangkat berdasarkan kriteria di bawah ini, antara lain: a) Dipilih yang paling banyak hafalannya dan paling fasih bacaannya; b) Yang paling faham terhadap Sunnah Rasulullah (SAW); c) Yang lebih dahulu hijrah; d) Yang lebih tua usianya; dan e) Tuan rumah (pribumi).

Adapun komitmen makmum (jama'ah) terhadap seseorang yang dijadikan Imam shalat maka hendaklah dia mengikutinya dengan ketentuan, antara lain: a) Tidak boleh mendahului (gerakan) Imam; b) Harus tunduk (mengikuti) Imam; dan c) Mengingatkan bila (Imam) mendapati sesuatu kesalahan atau kekeliruan yang dilakukan Imam.

Selain hal di atas, menurut Hammad Hasan Raqith, ada beberapa hal atau tata krama yang harus diperhatikan oleh seorang Imam menyangkut tugas dan tanggung jawab yang diembannya, antara lain: a) Bacaan Imam dalam shalat hendaknya jelas tidak dibuat-buat dapat didengar oleh makmum dengan harapan memberikan pengajaran danmensucikan juwajiwa mereka; b) Bersikap sederhana (bijaksana) dalam memimpin shalat denganmemperhatikan kondisi dan waktu para makmum. Jangan sampai terjadi, didapati orang yang tidak mau berangkat jama'ah ke masjid dikarenakan bacaan shalat yang dibaca imam terlalu panjang. Hal seperti ini Rasulullah (SAW) pernah menegur Mu'adz bin Jabal karena bacaannya yang panjang dalam shalat jama'ah, sebagaimana tersebut dalam hadits shahih, Rasulullah mengatakan, "Wahai Mu'adz, apakah engkau seorang pembuat fitnah? Bacalah begini,barangsiapa menjadi Imam shalat maka hendaknya dia meringankan (memilih bacaan yang pendek, karena di antara mereka terdapat orang yang lemah, orang yang sakit, dan orang yang sedang memiliki hajat (keperluan)." (H.R. Muslim); c) Thuma'ninah di dalam shalat. Tidak tergesa-gesa dan teriak cepat, baik dalam gerakan atau pada bacaannya orang yang melakukan seperti itu oleh Nabi (SAW) disebut sebagai orang yang "mencuri shalat" sebagaimana dalam suatu hadits disebutkan, "Seburuk-buruk pencuri (yang dilakukan) manusia adalah mencuri sebagian dari shalatnya. Mereka mengatakan, "Wahai Rasulullah, 
bagaimana mereka mencuri sebagian dari shalatnya? Rasulullah menjawab, "dia tidak menyempurnakan ruku' ataupun sujudnya". (HR. Ahmad dan AdDarimi); dan d) Temasuk tugas-tugas Imam masjid adalah berusaha memahamkan jama'ahnya tentang agama Islam, menganjurkan mereka kepada kebaikan, mencegah mereka dari kejahatan, memotivasi mereka untuk mengingat Allah (S.W.T) dan mendorong mereka untuk saling menopang dalam hal keimanan dan ketaqwaan.

\section{Tipologi Kepemimpinan Masjid}

Kepemimpinan adalah terjemahan dari leadership. Kata leadership diambil dari kata "to lead" yang artinya memimpin. Untuk kata pemimpin atau memimpin, di dalam literatur Islam digunakan sedikitnya empat istilah, antara lain yaitu; Imam, Wali atau Auliya, Ra'in. Imam adalah orang yang dimakmumi (dijadikan pemimpin) oleh orang lain, di antaranya adalah imam shalat. Maka seorang imam shalat memegang tanggung jawab menegakkan shalat berjama'ah dengan kaum muslimin di masjid.

Dengan demikian, kepemimpinan adalah kegiatan mengkoordinir, memotivasi dan mengarahkan individu atau kelompok untuk mencapai tujuan bersama. Adapun konsep dasar kepemimpinan dalam kepengurusan masjid, demikian pula pada organisasi-organisasi muslim lainnya adalah pengembanan amanah dan partisipasi, bukan perolehan kekuasaan dan masa bodoh. Amanah yang diemban pengurus masjid secara hablumminaLlah dipertanggungjawabkan kepada Allah dan secara hablumminan Naas kepada anggota dalam forum musyawarah anggota. Sebagaimana dijelaskan dalam Alqur'an surat An-Nisaa ayat 58.

Pengurus masjid sebagai pemimpin yang memimpin dan mengarahkan anggotanya, seharusnya berusaha membina keimanan, ibadah maupun akhlak mereka sesuai dengan batas-batasan tugas dan kewenangan yang dimilikinya. Kepempinan mengarahkan dan menganjurkan kepada taqwa dan kebajikan bagi semua. Sedangkan anggota sudah seharusnya rela untuk diatur, memberi dukungan serta berpastisipasi aktif dalam kegiatan-kegiatan yang dilaksanakan pengurus.

Dalam mengemban amanat kepemimpinan tersebut, pemimpin memiliki tipe atau gaya sendiri-sendiri. Mohammad Ayub (1996: 55), menyebutkan ada empat gaya kepemimpinan, antara lain sebagai berikut: a) 
Gaya kepemimpinan otoriter atau otokrasi, dengan ciri-cirinya sangat memaksakan, mendesakkan kekuasaan kepada bawahan; b) Gaya kepemimpinan demokrasi, dengan ciri; bersikap tengah antara memaksakan kehendak dan memberi kelonggaran kepada bawahan; c) Gaya kepemimpinan Laisses Faire, yakni memiliki sikap memberi kebebasan kepada bawahan; dan d) Gaya kepemimpinan situasional, yakni suatu sikap yang lebih melihat situasi; kapan harus bersikap memaksa, kapan harus moderat, dan pada situasi apa pula pemimpin harus memberikan keleluasaan pada bawahan.

Berdasarkan tipe-tipe di atas, tipe pemimpin masjid yang paling cocok menurut Mohammad Ayub (1996: 56), adalah tipe kepemimpinan situasional, dengan karakteristik sebagai berikut: a) Supel dan Luwes; b) Berwawasan luas; c) Mudah menyesuaikan diri dengan lingkungan; d) Mampu menggerakkan bawahan; e) Bersikap keras pada saat-saat tertentu; f) Berprinsip dan konsisten terhadap suatu masalah; g) Mempunyai tujuan yang jelas; h) Bersikap terbuka bila menyangkut bawahan; i) Mau membantu memecahkan permasalahan bawahan; j) Mengutamakan suasana kekeluargaan dan komunikatif; k) Mengutamakan produktifitas kerja; I) Bertanggungjawab dan mau memberikan tanggungjawab; m) Memberikan kesempatan pada bawahan untuk mengutarakan pendapat pada saat-saat tertentu; n) Melakukan atau mengutamakan pengawasan melekat; o) Mengetahui kelebihan dan kelemahan bawahan; p) Mengutamakan kepentingan bawahan; q) Bersikap tegas dalam situasi dan kondisi tertentu; dan r) Aspiratif; mau menerima saran dan kritikan dari bawahan.

Figur dengan karakteristik seperti itu akan mudah diterima oleh jama'ah yang pada kenyataannya sangat beragam. Jama'ah masjid memerlukan pemimpin yang ideal dan tidak kaku yang bisa diajak berbicara oleh lapisan sosial manapun. Pemimpin yang bertipe situasional merupakan pilihan paling efektif untuk kepentingan jama'ah Masjid. Sebab kepemimpinan lebih merupakan "Seni" ketimbang ilmu. Kenyataan kerap menunjukan, seseorang yang piawai menguasai disiplin ilmu tertentu belum tentu mampu memimpin. (Muhammad E. Ayyub, 1996 : 55-56).

Lebih jauh Ayub menjelaskan, pengurus masjid yang dalam melaksanakan tugas kegiatan pelaksanaan ibadah memihak satu golongan 
atau faham akan mengakibatkan jama'ah itu pasif. Dia menambahkan, menolak sikap/faham golongan yang kebetulan tidak sehaluan, di samping tidak memperlihatkan jiwa besar, juga akan menjadikan kegiatan masjid kehilangan gairah. Perbedaan faham dalam masalah khilafiyah, misalnya, bukan harga mati untuk menolak kerjasama yang berdimensi keagamaan. Adalah ironis jika pengurus masjid sampai terjebak pada fanatisme sempit atas nuansa perbedaan yang bersifat tidak terlalu prinsip. Oleh karena itu, pengurus masjid justru harus berangkat dari kesadaran dan pemahaman bahwa jama'ahnya beraneka ragam. (Muhammad E.Ayub, 1996:56).

Dengan demikian, hubungan dan kerjasama pengurus dengan jama'ah sangat diperlukan dalam mengatasi berbagai problematika "masjid. Tanpa kerjasama, masalah tetap tinggal masalah. Kerjasama sangatlah dibutuhkan terutama untuk meringankan pengurus dalam melaksanakan berbagai kegiatan (syi'ar Islam) di masjid. Dari tipologi pemimpin berbasis masjid inilah penulis dapat memberi catatan bahwa: a) Imam Masjid adalah orang yang memiliki wawasan yang lebih (faham ilmu agama) faham tentang ilmu Alqur'an dan As-Sunnah dan dasar-dasar ilmu agama Islam bacaannya fasih, banyak hafalannya) daripada makmumnya, dipercaya untuk memimpin jama'ah khususnya dalam berkomunikasi secara vertikal dengan Allah. Disamping itu, imam masjid harus dapat memahami kondisi objektif Masyarakat sekitarnya dari berbagai heterogenitas sosial, didalamnya termasuk mengetahui aliran (corak) pemahaman keagamaan yang berkembang dan dianut oleh masyarakat sekitarnya; b) Ketika makmum mendapati kekeliruan atau kesalahan yang dilakukan oleh Imam, maka makmum wajib mengingatkannya, tidak boleh berdiam diri. Begitu pula Imam shalat harus menyadari kesalahannya untuk mau diperbaiki atau dikoreksi, hal ini demi untuk menyelamatkan pelaksanaan dan kesempurnaan shalat jama'ah. Ini berarti, bahwa ketika seorang Imam atau pemimpin berbuat kesalahan maka harus bersedia menerima koreksi, kritik untuk diperbaiki. Begitu pula bawahan (masyarakat) harus berarti meluruskan kesalahan pemimpin. Karena bila dibiarkan itu terjadi maka akan menyebabkan kehancuran terhadap sistem kerja yang menjadi tanggung jawab semua pihak (atasan dan bawahan); dan c) Seorang pemimpin harus netral dan 
independent, yakni tidak mementingkan atau memihak kepada kepentingan salah satu kelompok, baik itu partai atau organisasi tertentu.

\section{Masjid sebagai Lembaga Pendidikan Islam}

Masjid berasal dari kata kerja "sajada" artinya sujud. Kata masjid menunjukan arti nama tempat yaitu tempat sujud. Masjid sebagai bangunan tempat shalat memiliki bentuk dan ukuran tertentu yang diadakan karena fungsinya, antara lain lantai segi empat yang menampung shaf-shaf yang diatur dari barisan terdepan sampai ke belakang (Departemen Agama RI, 1997: 223). Masjid juga berarti tempat "shalat berjama'ah" atau tempat shalat untuk umum (orang banyak). (Hasbullah,1995: 131).

Menurut Mursi, di masa lalu masjid adalah sebagai pusat pendidikan Islam yang paling vital, kemudian dari masjid itu lahirlah madrasah (sekolahsekolah) yang mempunyai andil yang sangat besar dalam pendidikan di negara-negara Islam Selain itu, masjid juga menjadi pusat perpustakaan Umat Islam. (Muhamrnad Munir Mursi, Tt: 199).

Sejalan dengan pendapat di atas, menurut Asrohah, masjid merupakan lembaga pendidikan Islam yang sudah ada sejak Nabi. la mempunyai peranan penting bagi masyarakat Islam sejak awal sampai sekarang. masjid berfungsi sebagai tempat bersosialisasi, tempat ibadah, tempat pengadilan dan sebagainya. Tetapi yang lebih penting adalah sebagai lembaga pendidikan (Hanun Asrohah, 2001 : 56).

Masjid merupakan institusi pendidikan yang pertama dibentuk dalam lingkungan Masyarakat muslim. Masjid sangat berperan penting dalam pendidikan Islam di Indonesia, dan bahkan sistem pendidikan atau surau dianggap sebagai lembaga pendidikan Islam tertua di Indonesia, sebelum adanya pesantren kemudiannya (Hanun Asrohah, 2001:56).

Masjid merupakan institusi pendidikan yang pertama dibentuk dalam lingkungan masyarakat musim. Masjid sangat berperan penting dalam pendidikan Islam di Indonesia, sebelum adanya pesantren kemudiannya (Hanun Asrohah, 2001: 132). Sementara itu, Al-Abrasyi dalam bukunya "AlMadkhal' menyatakan bahwa masjid merupakan tempat terbaik untuk kegiatan pendidikan. Dengan menjadikan dalam masjid akan terlihat hidupnya sunnah-sunnah dalam Islam, menghilangkan bid'ah-bid'ah, 
mengembangkan hukum-hukum Allah, serta menghilangkan stratifikasi rasa dan status ekonomi dalam pendidikan (Muhammad Athiyah Al-Abrasi : 271). Senada dengan pernyataan diatas, Muhammad Abdul Qodir Abu Faris mengemukakan, bahwa masjid mempunyai risalah yang melewati batas yang difahami manusia sekarang ini. Di antara fungsinya yang dominan itu adalah: a) Masjid sebagai sarana syi'ar peribadatan dan tempat menunaikan shalat berjama'ah yang merupakan tiang agama; b) Masjid sebagai universitas, tempat memberikan pengajaran Islam dan bimbingan dari Rasulullah SAW; c) Masjid sebagai sentral infomasi dan pengetahuan; d) Masjid sebagai tempat merajut ukhuwwah dan kebersamaan hidup. Lima kali kaum muslimin bertemu untuk saling mengenal dan menolong di antara mereka; e) Masjid sebagai sentral berkumpul dan pemberangkatan pasukan Islam, ketika Rasul sebagai panglima tertinggi memanggil mereka; f) Masjid juga berfungsi sebagai tempat bermusyawarah antara kaum muslimin. la ibarat majlis umat yang membahas berbagai problematika sosial, politik dan ekonomi (Muhammad Abdul Qodir Abu Faris, 2004: 109). Sejalan dengan pendapat di atas, Miftah Farid mengemukakan bahwa masjid adalah gambaran kecil dan suatu masyarakat Islam(miniatur masyarakat Islam), yang di dalamnya mengandung beberapa ajaran penting, antara lain: (1) Mengajarkan prinsip ukhuwah, persaudaraan. Pelaksanan ibadah shalat dengan menghadap kearah yang samatakbir bersama, ruku bersama, sujud bersama, dan lain-lain, menggambarkan nilai-nilai kebersamaan dan persaudaraan dalam Islam; (2) Prinsip Musawah, persamaan derajat dihadapan Allah (S.W.T). Keharusan adanya shaf yang lurus dengan tidak membedakan pangkat, kedudukan dan kekayaan, bahu beradu dengan bahu, danlain-lain, ini menunjukkan adanya persamaan derajat; (3) Prinsip Imamah. Peragaan shalat berjama'ah di masjid memiliki beberapa aturan diantaranya: (a) Keharusan adanya pemimpin; (b) Cara pemilihan penumpin; (c) Kriteria yang paling berhak menjadi pemimpin; (d) Ketaatan terhadap pemimpin; (e) Koreksi terhadap pemimpin; (f) Kesediaan pemimpin menerima koreksi (aspiratif dan terbuka); dan (h) Pergantian pemimpin, dan lain-lain; g) Masjid sebagai pusat kegiatan dakwah. Di masjid dikumandangkan khutbah, ceramah, ta'lim, tabligh, pendidikan, pengajaran, musyawarah, dan lain sebagainya. Dari masjid hendaknya keluar kalimat 
hasanah dan thayyibah, kalimat-kalimat yang agung dan mulia; h) Masjid merupakan peradaban Islam, masjid adalah tempat umat Islam berkreasi dan berprestasi, tempat belajar dan mengajar, tempat berzikir, tempat Umat Islam berjihad dan berijtihad, dan tempat bermusyawarah (Miftah Farid: 1995).

Dengan demikian, masjid sudah merupakan lembaga kedua setelah keluarga, yang jenjang pendidikannya terdiri dari sekolah menengah dan sekolah tinggi dalam waktu yang sama. (Hasan Langgulung, 1988:111).

Oleh sebab itu, implikasi masjid sebagai lembaga pendidikan Islam menurut Abdurrahman An-Nahlawi adalah berfungsi untuk: a) Mendidik anak untuk tetap beribadah kepada Allah; b) Menanamkan rasa cinta kepada ilmu pengetahuan dan menanamkan solidaritas sosial, serta menyadarkan hakhak dan kewajibannya sebagai insan pribadi, sosial dan warga Negara; dan c) Memberi rasa ketentraman, kekuatan dan kemakmuran potensi-potensi rohani manusia melalui pendidikan kesabaran, keberanian, kesadaran, optimisme, dan pengadaan penelitian (Abdurrahman An- Nahlawi, 1979 :13).

Dari beberapa pendapat yang dikemukakan di atas tentang fungsi dan peranan masjid, maka dapat difahami bahwa begitu pentingnya kedudukan masjid sebagai sebuah lembaga pendidikan Islam di mana masjid berfungsi sebagai Islamic Center atau sentral kegiatan-kegiatan syi'ar Islam, baik itu kegiatan pendidikan keagamaan, dakwah, sosial dan kebudayaan bagi kaum muslimin hingga saat ini.

\section{PEMBAHASAN}

\section{Fungsi Edukatif Masjid}

Aktivitas pertama Rasulullah ketika tiba di Madinah adalah membangun masjid, karena masjid merupakan tempat yang dapat menghimpun berbagai jenis kaum muslimin (Islam tidak membeda-bedakan etnis, ras atau golongan, karena yang dinilai di sisi Allah (S.W.T) adalah ketaqwaannya). Di dalam masjid, seluruh muslim dapat membahas dan memecahkan persoalan hidup, bermusyawarah untuk mewujudkan berbagai tujuan, menjauhkan diri dari kerusakan, serta menghadang berbagai penyelewengan aqidah. Bahkan Masjid pun menjadi tempat mereka berhubungan dengan penciptanya dalam rangka memohon ketentraman, 
kekuatan dan pertolongan dari Allah (S.W.T) Di Masjid, mereka mengisi hatinya dengan kekuatan spiritual sehingga Allah (S.W.T) selalu menganugerahkan kesabaran, ketangguhan, kesadaran, kewaspadaan serta aktivitas yang penuh semangat. (Abdur Rahman An-Nahlawi, 1995: 137).

Pada awal penyebaran Islam, masjid memiliki fungsi mulia yang bisa jadi sekarang ini mulai terlupakan. Pada zaman itu, masjid digunakan sebagai markas besar tentara dan pusat gerakan pembebasan Umat dari penghambaan kepada manusia, berhala atau thaghut. Makna thagut ialah setan dan apa saja yang disembah selain Allah. (Tafsir al-Qur'an surat alBaqarah ayat 256).

Masjid pun digunakan sebagai pusat pendidikan yang mengajak manusia kepada keutamaan, kecintaan pada pengetahuan, kesadaran sosial, serta pengetahuan mengenai hak dan kewajiban mereka terhadap negara Islam yang pada dasarnya didirikan untuk mewujudkan kepada tegaknya syari'at, keadilan, dan rahmat Allah (S.W.T). Masjid dimanfaatkan juga sebagai pusat gerakan penyebaran akhlak Islam dan pemberantasan kebodohan.Kondisi sepmi ini terus berlanjut hingga dalam perkembangannya sekarang ini mengalami berbagai pasang surut yang kadang-kadang menjadikan Masjid berfungsi sebagai ajang penonjolan fanatisme madzab, golongan, atau kepentingan individu.

\section{Fungsi Sosial Masjid}

Ketika bencana atau petaka menerpa kaum mukminin, masjid dapat digunakan sebagai tempat berlindung. Di sana umat Islam dapat menyusun kekuatan untuk mengibarkan panji-panji Islam dan meninggikan kalimah Allah sebagaimana pernah terjadi dalam perang Salib pertama atau dalam berbagai gerakan pembebasan melawan tentara Salib dan Yahudi dalam perang Salib kedua. Yang jelas, ketika itu kaum Muslimin melawan kaum penjajah yang bercokol selama satu abad di berbagai negara Islam. Revolusi Siria bergema dari masjid besar yang ada di kota-kota Siria. Revolusi alJazair pun berbasis di pondok-pondok dan sekolah-sekolah Islam yang berada di masjid-masjid. Demikian pula gerakan kemerdekaan Islam lainnya, seperti di Pakistan, Afganistan, dan negara lainnya. (Abdur Rahman AnNahlawi, 1995:138). Bahkan, kegagalan kudeta yang dilancarkan militer anti Islam Turki belum lama ini juga karena rakyat muslim Turki dipersatukan dan 
digerakkan oleh kekuatan jamaah yang berpusat dari masjid. Demikianlah, manusia dibina dan dididik di masjid-masjid dalam naungan masyarakat muslimyang tinggi dan mengutamakan musyawarah dalam penyelesaian masalahnya. Jama'ah yang sakit mereka tengok dan orang fakir miskin yang membutuhkan pertolongan, mereka beri rizki (bantuan), yang mereka terima dari Allah. Maka jadilah mereka masyarakat yang kuat, bersatu, berpatisipasi dalam pendidikan dan pembangunan umat melalui program back to mosque (memberdayakan masjid).

\section{Dampak Edukatif dan Sosial Masjid}

Masjid yang didirikan atas dasar ketaqwaan kepada Allah (S.W.T) menjadi sarana efektif dalam melaksanakan pembinaan spiritual kaum muslimin disebabkan semangat keagamaan yang menekankan pada penguatan aspek keimanan dan terimplementasikan dalam bentuk aktivitas ubudiyah, baik secara vertikal (hablun minallah) maupun secara horizontal (hablun minan Naas). Pola pembinaan ubudiyah di masjid secara berjama'ah telah mengajarkan cara hidup bermasyarakat yang baik, semangat persatuan yang dilandasi persaudaraan atas dasar iman berdampak lebih luas terhadap kehidupan manusia untuk saling memberi manfaat, menyatukan setiap potensi, bersinergi dan saling menguatkan.

Di masjid itulah terkumpul kaum mukminin atas nama Allah (S.W.T) yang di dalam dirinya berkembang pengakuan dan kebanggaan sebagai masyarakat muslim. Di masjid, mereka akan menyimak pendidikan keagamaan dan berbagai pengetahuan umum sehingga mereka menjalani hidup dengan kesadaran atas akidah Islam, penuh pemahaman atas tujuan hidup dan bersyukur atas apa yang disediakan Allah (S.W.T) untuk kepentingan dunia dan akhirat mereka. Mereka mempelajari Alqur'an dan membacanya dengan tertib sehingga mereka mampu menyeimbangkan perkembangan pula pikir dan peradabannya dengan undang-undang Masyarakat Islam dan perkembangan spiritual yang menjadi pengikat dirinya kepada Sang Khaliq. Hadits, fiqih dan segala ilmu kemasyarakatan pun mereka pelajari di masjid, termasuk di dalamnya ilmu yang berhubungan dengan bahasa, sejarah dan sebagainya. Namun, dari semua itu yang paling penting, melalui masjid, setiap muslimdapat melakukan pertemuanpertemuan dalam rangka ketaatan kepada Allah (S.W.T). Jika ternyata, 
pertemuan itu dilakukan menjelang shalat fardhu', mereka menyusun shaf dan mendahulukan shalat. Jika ternyata pertemuan itu dilakukan tidak pada waktu shalat fardhu, mereka bermusyawarah sambil menantikan datangnya waktu shalat dan melanjutkan musyawarahnya atau memutuskan suatu masalah setelah shalat selesai. (Abdnr Rahman An-Nahlawi, 1995 :138).

Pemanfaatan masjid seperti itu akan mendidik manusia untuk mengaitkan segala persoalan hidup pada ikatan karena Allah (S.W.T) yang bersumber pada pendidikan Islam yang universal, yaitu penghambaaa diri kepada Allah (S.W.T). Dan itu harus tertanam dalam diri manusia secara ikhlas tanpa merasa terbebani.

\section{Eksistensi Masjid}

Dewasa ini umat Islam terus menerus mengupayakan pembangunan masjid. Bermunculan masjid-masjid baru di berbagai tempat, disamping renovasi atas Masjid-masjid lama. Semangat mengupayakan pembangunan rumah-rumah Allah (S.W.T) itu layak dibanggakan. Hampir di seluruh tanah air tidak ada yang tidak tersentuh oleh pembangunan masjid. Ada yang berukuran kecil tapi mungil, dan ada yang berukuran besar dan megah. Namun tidak sedikit pula masjid yang terkatung-katung pembangunannya dan tidak kunjung rampung, terutama di daerah-daerah yang solidaritas jamaahnya belum kuat (Muhammad. E. Ayyub, 1997 : 15).

Setelah bangunan masjid itu berdiri, volume kegiatan yang berlangsung di dalamnya juga beragam. Ada yang mampu mengintensifkan kegiatannya seharian penuh dengan menyelenggarakan tingkat pendidikan rendah sampai tinggi. Sebaliknya, tidak sedikit jumlah masjid yang pembangunannya diusahakan dengan susah payah justru sepi dan kegiatan (syiar). Banyak dijumpai di sana-sini masjid berfungsi hanya satu minggu sekali, hanya untuk shalat jumat saja.

Pada zaman dahulu, mereka yang membangun masjid mulai dari pengurusannya sampai tukangnya adalah para iltizam, yaitu pribadi-pribadi yang mempunyai komitmen dengan Islam. Kini menghimpun dan mengumpulkan sejumlah manusia bertaqwa semacam itu merupakan pekerjaan sulit. Maka kompromi dengan kondisi dan situasi objektif dengan zaman mesti diambil. Dalam perkembangannya, sebagaimana yang terjadi 
saat ini, bahwa terkadang panitia pembangunan masjid begitu antusias aktif di masjid ketika proses berlangsungnya pembangunan masjid,karena memang itu menjadi resiko yang logis. Namun, begitu masjid telah berdiri, seakan tanggung jawabnya juga selesai dan mereka hanya sesekali mengunjungi masjid. Ironisnya, hal-hal seperti itupun makin menjadi pemandangan biasa, sebagai "Proyek" si pemborong yang terbiasa berfikir dalam perhitungan benefit menggunakan para pekerja. Mereka bekerja keras membangun masjid bahkan tinggal di masjid, tetapi tidak pernah melaksanakan shalat. Bagi mereka tidak ada bedanya antara kerja membangun gedung biasa dengan mendirikan masjid.Belum pernah adapihak yang memberlakukan sanksi bagi para pekerja di masjid yang tidak shalat. Mungkin saja ada yang menasehati mereka tetapi tidak sampai pada tindakan pemecatan. Padahal, tidak sedikit pemborong bangunan yang berpredikat haji (Muhammad, E. Ayyub,1997 : 15).

Jika dilihat dari fungsinya, seharusnya setelah masjid itu berdiri dalam rangka membangun mentalitas dan peradaban umat. Dengan demikian, secara teoritis mestinya terdapat hubungan timbal balik yang saling memaknai antara keduanya. Kalau pada mulanya "umat membangun masjid" sekarang saatnya "masjid yang membangun umat". Keterikatan semacam ini, khususnya di desa-desa belum terlihat. Karena itu perlu dikaji kembali fungsi masjid yang sesungguhnya sebagaimana fungsi masjid di zaman Rasulullah, yakni "masjid didirikan atas dasar taqwa", sehingga masjid berfungsi yang sesungguhnya dan berlaku secara permanen sepanjang waktu.

Rasulullah memakmurkan masjid sebagai tempat pembinaan Umat. Benang merah kemakmuran masjid dirangkai dari pembinaan yang intensif. Pada zaman Nabi, masjid senantiasa padat dengan kegiatan syi'arnya, terutama shalat berjama'ah, sehingga masjid tidak pernah sepi dari kegiatan ubudiyah untuk meningkatkan taqwa. Keadaannya berbeda dengan zaman ini, wujud/fisik masjid begitu megah, namun sepi dari kegiatan syi'ar Islam, hal ini merupakan penyimpangan fungsi yang sesungguhnya. Ketidakberdayaan masjid sebagai media pembinaan umat terlihat dengan jelas, terutama di masjid-masjid perkampungan. Suara adzan pun terkadang jarang dikumandangkan setiap awal waktu shalat, apalagi waktu subuh. 
Begitu pula di kota-kota, banyak masjid yang berdiri megah, indah, tempatnya strategis namun jama'ahnya hanya beberapa orang saja, lebihlebih pada waktu shalat subuh.

\section{SIMPULAN}

Dari uraian yang telah dipaparkan di atas, bermula dari sejarah kepemimpinan masjid, peranan dan fungsi kelembagaan masjid. Penulis mencoba menarik benang merah dari karakteristik kepemimpinan berbasis masjid. Bahwa seorang pemimpin hendaklah memiliki beberapa kariteria yang perlu ditanamkan, antara lain sebagai berikut: 1) Kepemimpinan berbasis masjid dapat melahirkan pemimpin yang baik, yaitu pemimpin yang berorientasi pada pembinaan umat, sehingga dapat melahirkan pribadipribadi yang bertaqwa, mampu mengarahkan dan menghantarkan bawahan (generasi) untuk mencapai cita-citanya, yakni membentuk pribadi-pribadi yang beriman dan bermaslahat bagi dirinya, keluarganya, masyarakat dan agamanya. Untuk itulah, nilai-nilai luhur kepemimpinan yang diajarkan Islam hanya dapat dilaksanakan secara maksimal jika pelakunya seorang mukmin. Karena seorang mukmin akan menyadari bahwa kebaikan yang dilakukannya akan mendapat pahala, sedangkan keburukan yang diperbuat akan berakibat datangnya azab; 2) Keahlian yang teruji dipadu dengan integritas pribadi yang terpuji membuat seorang pemimpin mudah diterima oleh masyarakat. Tegasnya seorang pemimpin harus memiliki kemampuan dan keahlian (kapabilitas), ini merupakan syarat mutlak dalam meletakan amanah di pundak seseorang. Seperti disebutkan dalam teori manajemen, "The right man on the right place" (orang yang tepat di tempat yang benar). Rusaknya sebuah sistem organisasi, banyak diakibatkan oleh penempatan tugas dan amanah secara asal-asalan, yang seringkali dilatari oleh kepentingan dan subyektifitas; 3) Pemimpin yang baik senantiasa mengupayakan terwujudnya kemaslahatan umat. Aspek inilah yang banyak diabaikan oleh pemimpin mat saat ini Orientasi kepemimpinan yang semestinya ditujukan kepada kemaslahatan umat berubah ke arah kepentingan dan kekuasaan. Padahal Rasulullah Shallallahu 'alaihi wasallamsudah memberi peringatan keras, "Siapa yang memimpin dan ia tidak memperhatikan urusan kaum muslimin, maka ia tidak termasuk dalam 
golongan mereka". (HR Bukhari dan Muslim). Selain itu, seorang pemimpin hendaknya tidak arogan, tidak otoriter tetapi bersedia menerima koreksi. Pemimpin yang baik juga memiliki karakter bersahaja dan bijaksana; 4) Pemimpin yang ideal adalah yang berkualitas, baik dari segi fisik, mental dan intelektual. Kematangan dalam segi-segi ini sangat membantu seorang pemimpin dalam melaksanakan tugas. Pengetahuan dan wawasan yang luas, kunci dalam memecahkan berbagai persoalan yang menghadang atau melakukan terobosan-terobosan penting bagi keberhasilan tugas seorang pemimpin. Islam sangat menganjurkan kepada setiap muslim untuk memiliki tiga jenis kekuatan ini, yaitu;bahwa mukmin yang kuat dan baik lebih dicintai oleh Allah SWT dari pada mukmin yang lemah, masing-masing mempunyai kebaikan.

Dalam kenyataannya, kepemimpinan seseorang memang tak bisa membuat semua orang lega.Walaupun demikian, seorang pemimpin yang memiliki program yang benar dan sudah dimusyawarahkan dengan penasehat-penasehat yang berpengalaman, tak boleh mundur dan patah semangat. Tentu saja, ia juga harus memiiiki tim kerja yang solid dan mumpuni, yang sanggup menerjemahkan visi menjadi bukti, tidak sekedar mengumbar harapan palsu, janji tanpa bukti, atau hanya pintar berkarya dengan kata tanpa berkarya dengan nyata.

Mudah-mudahan pada setiap pribadi pemimpin di negeri ini, baik pemimpin agama terlebih pemimpin bangsa dan negara benar-benar terdapat potensi seperti yang diidamkan oleh seluruh rakyat negeri tercinta ini sebagaimana karakteristik pemimpin berbasis masjid serta berkomitmen dalam mewujudkan visi dan misinya, dalam upaya membawa seluruh rakyatnya pada peningkatan kelayakan hidup yang lebih sejahtera, damai, adil, dan makmur serta berwibawa dalam kancah pergaulan internasional.

\section{DAFTAR PUSTAKA}

Al-Qur'an dan Terjemahnya, Madinah Al-Munawarah, KSA: Komp. Percetakan Al-Qur'an al-Karim Raja Fahd, $1419 \mathrm{H}$.

Al-Hadits. Shahih Bukhari Muslim, Tt . 
Abu Faris, Muhammad Abdul Qodir, Menelusuri Jejak Hijrah Nabi (Terj.) Nurqosim, Jakarta: Pustaka Qalami, 2004.

Al-Abrasy, Muhammad Atiyah, Dasar-Dasar Pokok Pendidikan Islam. Jakarta: Bulan Bintang, 1970.

Ruh Al-Tarbiyah Wa Al-Ta'lim, Saudi Arabia: Tt. X.

Asrohah, Hanun, Sejarah Pendidikan di Indonesia, Jakarta: Logos Wacana IImu, 2001, Cet. II.

An-Nahlawi, Abdurrahman, Ushul Al-Tarbiyah al-Islam wa Asaalibuha. Beirut: Darul Fikr, 1979.

Pendidikan Islam di Rumah, Sekolah dan Masyarakat, (Terj.) Jakarta: Gema Insani Press, 1995.

Departemen Agama RI, IImu Pendidikan, Jakarta; Dirjen Pembinaan Kelembagaan Agama Islam, 1997.

E. Ayub, Muhammad, dkk, Manajemen Masjid, Jakarta: Gema Insani Press. 1996.

Farid, Miftah, Masjid, Bandung: Pustaka,1995, Cet-II.

Hasbullah, Sejarah Pendidikan Islam di Indonesia, Jakarta: PT Raja Grafindo Persada, 1995.

Langgulung, Hasan, Asas-Asas Pendidikan Islam, Jakarta: Pustaka AlHusna, 1988.

Mursi, Muhammad Munir, Al-Tarbiyah Al-Islamiyah, Qatar: Muntaqah Darul Ma'arif, $\mathrm{Tt}$

Raqith, Hamad Hasan, Mas'uliyatud Da'wah Ilallah, (terj.). Ibnu Burdah: Meraih Sukses Perjuangan Da'i, Yogyakarta : Mitra Pustaka, 2001.

Siswanto, Panduan Praktis Organisasi Remaja Masjid, Jakarta: Pustaka AlKautsar, 2005. 